Пространственная Экономика

2010. № 2. C. $153-160$

\title{
УДК 336.02
}

\author{
3. Б.- $\Delta . \Delta$ oнgokов, А. В. Потапов
}

\section{ПРОБАЕМЫ ФИНАНСИРОВАНИЯ

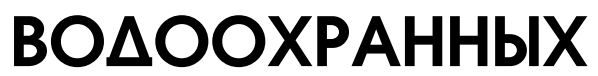 И ВОАОХОЗЯЙСТВЕННЫХ МЕРОПРИЯТИЙ В РЕСПУБАИКЕ БУРЯТИЯ}

Исследовано развитие системы платежей за пользование водными объектами в Российской Федерации. Выявлена проблема недостаточного финансирования водоохранных и водохозяйственных мероприятий в Республике Бурятия в условиях жестких экологических ограничений Байкальской природной территории. Обоснована необходимость изменений в бюджетном законодательстве России по водному налогу и плате за пользование водными объектами и внесены соответствующие предложения.

Пользование водными объектами, платежи, водный налог, водоохранные и водохозяйственные мероприятия, Байкальская природная территория, экологические зоны, Бюджетный кодекс РФ, Республика Бурятия.

Значительная часть Республики Бурятия в силу «байкальского фактора» относится к территориям с особым экологическим режимом. На долю Бурятии приходится 69,4\% площади водосборного бассейна озера Байкал. Практически вся наиболее хозяйственно освоенная и обжитая часть территории республики, составляющая более половины территории, входит в Байкальскую природную территорию (БПТ) и находится под действием особого режима природопользования, установленного федеральным законом от 01.05.1999 г. № 94-Ф3 «Об охране озера Байкал» [8]. «Особый» режим

() Дондоков 3. Б.-Д., Потапов Л. В., 2010 
№ 22010

предусматривает ликвидацию и перепрофилирование экологически опасных хозяйственных объектов, а также повышенные требования к хозяйствующим субъектам в части соблюдения предельно допустимых вредных воздействий на уникальную экологическую систему озера Байкал.

Наиболее жесткие ограничения установлены на территории центральной экологической зоны (38,048 тыс. км²), в которой введен запрет на сплошные рубки лесных насаждений, добычу любых полезных ископаемых, строительство зданий и сооружений (или их частей), функционирование которых не связано с созданием и развитием особо охраняемых природных территорий федерального значения и особых экономических зон туристско-рекреационного типа. В меньшей степени регулируется хозяйственная деятельность В буферной экологической зоне (133,374 тыс. км²).

В целом, по оценкам министерства экономики Республики Бурятия, объем валовой добавленной стоимости, недополученной Республикой Бурятия в результате экологически обусловленных потерь и недопроизводства продукции, составил в 2005 г. 7,8 млрд руб., в 2006 г. - 8,8 млрд руб., в 2007 г. 10,1 млрд руб. и сопоставим с годовым объемом осуществляемых в республике инвестиций.

При этом на республику возложены обязанности по поддержанию водного режима в бассейне озера Байкал. Основным источником финансирования водоохранных и водохозяйственных мероприятий, проводимых в Бурятии в связи с такой обязанностью, до 2005 г. являлись платежи за пользование водными объектами, которые поступали в бюджет республики. Это обусловливало то, что большая часть средств на водоохранные и водохозяйственные мероприятия выделялась из бюджета республики (80,8\% в 2003 г. и 81,9\% в 2004 г.).

Пополнение республиканского бюджета для последующего финансирования вышеуказанных мероприятий обеспечивалось переходом с 1991 г. к принципу платности природопользования, который заменил бесплатность водопользования, закрепленную в Водном кодексе РСФСР в советский период развития [3]. В 1991 г. был принят закон РСФСР «Об охране окружающей природной среды», в котором была введена плата за природные ресурсы (землю, недра, воду, лес и иную растительность, животный мир, рекреационные и другие природные ресурсы) [9]. С 1995 г. порядок водопользования стал регулироваться Водным кодексом РФ [4]. В соответствии с ним права пользования водными объектами приобретались на основании лицензии на водопользование и заключенного в соответствии с ней договора пользования водным объектом.

Конкретные условия и порядок взимания платы за воду были установлены федеральным законом «О плате за пользование водными объектами» от 06.05.1998 г. №71-Ф3 [7]. В соответствии с ним объектом платы признава- 
лось пользование водными объектами в целях осуществления забора воды из водных объектов, удовлетворения потребности гидроэнергетики в воде, осуществления сброса сточных вод и использования акватории для производственных целей. Отличительными особенностями этого закона являлись:

1. Высокий уровень законодательной инициативы субъектов Российской Федерации. Ставки платы по категориям плательщиков в зависимости от вида пользования водными объектами, состояния водных объектов и с учетом местных условий водообеспечения населения и хозяйственных объектов устанавливались законодательными (представительными) органами субъектов РФ в пределах указанных диапазонов. Кроме того, законодательные (представительные) органы субъектов РФ были вправе принимать решения о зачислении в местные бюджеты всей суммы платы или ее части, поступающей в их бюджеты.

2. Децентрализация платежей за пользование водными объектами. Суммы платы до 2002 г. зачислялись в федеральный бюджет и бюджеты субъектов РФ в следующем соотношении: $40 \%$ - в федеральный бюджет, $60 \%$ в бюджеты субъектов РФ. В период с 2002 по 2004 г. вся плата за пользование водными объектами (100\%) поступала в региональные бюджеты. Исключение составили лишь платежи за добычу подземных вод, которые зачислялись в федеральный бюджет и бюджеты субъектов РФ в прежнем соотношении.

3. Межрегиональный характер платежеей. При пользовании водными объектами, расположенными на территориях двух и более субъектов РФ, суммы платы за пользование водными объектами вносились в бюджет субъекта РФ по месту регистрации плательщика с последующим их распределением между бюджетами тех субъектов РФ, на территориях которых находятся такие водные объекты. При этом доля поступлений сумм платы в бюджет соответствующего субъекта РФ определялась бассейновыми соглашениями между субъектами РФ.

4. Целевая направленность платежей. Поступления сумм платы направлялись на осуществление мероприятий по восстановлению и охране водных объектов в объеме не менее $50 \%$.

Это создавало возможность для субъектов РФ аккумулировать плату за водные ресурсы и финансировать конкретные мероприятия по рациональному их использованию и охране. Но с 1 января 2005 г. вступила в действие глава «Водный налог» (№ 25.2) Налогового кодекса РФ [5]. В соответствии с этой главой водный налог был включен в перечень федеральных налогов и сборов. В целом принятие этой главы породило несколько важных изменений в действовавшей системе налогообложения и финансирования водного хозяйства: 
1) были установлены фиксированные ставки налога по каждому виду водопользования в зависимости от экономического района, бассейна реки, озера или моря;

2) вся сумма платежей по водному налогу стала зачисляться в федеральный бюджет;

3) прекратили действие бассейновые соглашения и, соответственно, перестали распределяться между субъектами РФ суммы платежей за пользование водными объектами, расположенными на территориях двух и более субъектов РФ;

4) был отменен целевой характер платежей.

В результате платежи за пользование водными объектами оказались централизованными в федеральном бюджете.

1 января 2007 г. вступил в действие новый Водный кодекс РФ, в соответствии с которым (статья 8) все водные объекты находятся в собственности Российской Федерации [2]. Исключение составляют лишь пруды и обводненные карьеры, расположенные в границах земельного участка, принадлежащего на праве собственности субъекту РФ, муниципальному образованию, физическому лицу, юридическому лицу. При этом упраздняется лицензирование водопользования. Водные объекты стали предоставляться в пользование по договору водопользования на срок до 20 лет. Водный налог постепенно (по мере истечения сроков действия ранее выданных лицензий на водопользование) будет вытеснен неналоговой платой за пользование водными ресурсами в соответствии с договорами по ставкам, устанавливаемым Правительством Российской Федерации, органами государственной власти субъектов РФ, органами местного самоуправления соответственно формам собственности на водные объекты.

С точки зрения субъектов РФ эти новации малозначимы, так как практически вся сумма платежей за пользование водными объектами продолжит поступать в федеральный бюджет. Доля водных объектов, остающихся в собственности субъектов РФ и муниципальных образований, очень мала, поэтому лишь незначительная часть платежей за пользование водными объектами поступает в региональные и местные бюджеты.

Введение нового порядка платежей за водопользование привело к обострению проблем финансирования водоохранных и водохозяйственных мероприятий. Особенно негативно это сказалось в субъектах РФ с активным водопользованием, к которым относится Республика Бурятия (РБ).

До 2005 г. в бюджет Республики Бурятия поступали два вида платежей за водопользование (см. табл. 1):

- плата за пользование водными объектами на территории РБ;

• платежи в бюджет РБ по Бассейновому соглашению между Респуб- 
ликой Бурятия и Иркутской областью о разделе сумм платы за пользование водными ресурсами озера Байкал, подписанному руководителями этих субъектов РФ в 1999 г.

Таблица 1

Объемы поступления и использования платежей за пользование водными объектами на территории Республики Бурятия, млн руб.

\begin{tabular}{l|c|c}
\hline \multicolumn{1}{c|}{ Показатель } & 2003 & 2004 \\
\hline Всего поступлений за пользование водными объектами & 132,9 & 157,9 \\
\hline $\begin{array}{l}\text { сумма поступлений платы за пользование водными } \\
\text { объектами на территории РБ }\end{array}$ & 109,9 & 132,5 \\
\hline платежи в бюджет РБ по Бассейновому соглашению & 23,0 & 25,3 \\
\hline $\begin{array}{l}\text { Выделено на проведение водоохранных и водохозяйственных } \\
\text { мероприятий в РБ }\end{array}$ & 25,6 & 31,6 \\
\hline из бюджета РБ & 20,7 & 25,9 \\
\hline \multicolumn{1}{|c|}{ из бюджета Российской Федерации } & 4,9 & 5,7 \\
\hline Процент целевого использования & $\begin{array}{c}19,3 \\
15,6^{*}\end{array}$ & $\begin{array}{c}20,0 \\
16,4^{*}\end{array}$ \\
\hline
\end{tabular}

Примечание. * Без учета финансирования по программной части из бюджета РФ.

Источник: рассчитано по данным министерства экономики Республики Бурятия.

В соответствии с Бассейновым соглашением распределению подлежали суммы платы АОЭиЭ «Иркутскэнерго» за пользование водными ресурсами озера Байкал для выработки электроэнергии. Распределение сумм между субъектами РФ производилось по акваториальному принципу: пропорционально площадям акватории озера, отнесенным к субъектам РФ в соответствии с установленной границей между Республикой Бурятия (62\%) и Иркутской областью (38\%). В первые годы сумма платы за пользование водными ресурсами Байкала была незначительной. В 1999 г. она составила 671 тыс. руб., в 2000 г. - 776 тыс. руб., а в 2001 г. - 1530 тыс. руб. Полученные средства были направлены на выполнение мероприятий по охране озера Байкал.

С выходом федерального закона от 07.08.2001 г. № 111-Ф3 «О внесении изменений и дополнений в федеральный закон «О плате за пользование водными объектами» и постановления Правительства РФ от 28.11.2001 г. № 826 «Об утверждении минимальных и максимальных ставок платы за пользование водными объектами по бассейнам рек, озерам, морям и экономическим районам» ставки платы были увеличены до максимального размера [6, 10]. В силу этого платежи в бюджет Республики Бурятия по Бассейновому соглашению резко возросли, достигнув в 2004 г. суммы 25,3 млн руб.

После перевода платежей за водопользование в форме водного налога в бюджет Российской Федерации (2005 г.) их объем значительно увеличился 
частично за счет роста объема водопользования (в 1,5 раза) при фактически неизменной численности плательщиков (табл. 2). Республика Бурятия при этом, лишившись поступлений в республиканский бюджет водного налога и платежей по Бассейновому соглашению от АОЭиЭ «Иркутскэнерго», потеряла, по оценкам, порядка 200-250 млн руб. в год.

Таблица 2

Налоговая база и объем поступлений водного налога по Республике Бурятия

\begin{tabular}{|c|c|c|c|c|}
\hline Показатель & 2005 & 2006 & 2007 & 2008 \\
\hline Объем водопользования, млн м ${ }^{3}$ & 351,0 & 297,0 & 425,0 & 523,6 \\
\hline Количество налогоплательщиков & 214 & 206 & 204 & 221 \\
\hline $\begin{array}{l}\text { Сумма водного налога, поступив- } \\
\text { шая в бюджет РФ, млн руб. }\end{array}$ & 327,6 & 161,3 & 190,8 & 296,9 \\
\hline
\end{tabular}

Источник: составлено на основе данных Управления Федеральной налоговой службы России по Республике Бурятия.

Кроме того, особый режим природопользования БПТ предполагает не только соблюдение ограничений на хозяйственную деятельность, но и проведение специальных мероприятий по охране экологической системы Байкала, в том числе водоохранных и водохозяйственных.

Отметим, что в последние годы объемы финансирования водоохранных и водохозяйственных мероприятий в Республике Бурятия возрастали, достигнув максимума в 2009 г. (см. табл. 3).

Таблииа 3

Объемы финансирования водоохранных и водохозяйственных мероприятий в Республике Бурятия

\begin{tabular}{l|c|c|c|c}
\hline \multirow{2}{*}{ Наименование показателя } & \multicolumn{4}{|c}{ Объем финансирования, млн руб. } \\
\cline { 2 - 5 } & 2007 & 2008 & 2009 & $2010 *$ \\
\hline $\begin{array}{l}\text { Субвенции из федерального бюджета на финансиро- } \\
\text { вание мероприятий в области водных отношений }\end{array}$ & 14,5 & 52,1 & 55,9 & 37,3 \\
\hline $\begin{array}{l}\text { Субсидии на осуществление капитального ремонта } \\
\text { гидротехнических сооружений в Республике Бурятия }\end{array}$ & 9,6 & 15,6 & 30,0 & 11,2 \\
\hline за счет средств федерального бюджета & 9,0 & 12,0 & 23,0 & 10,0 \\
\hline за счет средств субъекта РФ & 0,6 & 3,6 & 2,2 & 1,0 \\
\hline за счет средств муниципального бюджета & - & - & 4,8 & 0,2 \\
\hline $\begin{array}{l}\text { Итого объем финансирования водоохранных и водо- } \\
\text { хозяйственных мероприятий }\end{array}$ & 24,1 & 67,7 & 85,9 & 48,5 \\
\hline
\end{tabular}

Примечание. * Плановые показатели.

Источник: составлено на основе данных министерства природных ресурсов Республики Бурятия. 
Положение резко ухудшилось в 2010 г. Так, из шести инвестиционных проектов, направленных на реализацию водоохранных и водохозяйственных мероприятий и предусмотренных Программой социально-экономического развития Республики Бурятия на 2008-2011 гг. и на период до 2017 г., с 2010 г. предусмотрено финансирование лишь двух из них.

Принятие федеральной целевой программы «Охрана озера Байкал и социально-экономическое развитие Байкальской природной территории», разрабатываемой Правительством РФ, позволит снизить остроту проблемы финансирования на территории водоохранных и водохозяйственных мероприятий. В проекте концепции данной программы на реализацию природоохранных мероприятий на период с 2011 по 2020 г. планируется выделить значительные суммы, в т. ч. за счет средств бюджета Республики Бурятия более 7 млрд руб. Вместе с тем в условиях хронического дефицита бюджета Бурятия не имеет достаточных ресурсов для финансирования мероприятий. С учетом особой экологической ситуации в Байкальском регионе Республика Бурятия должна иметь достаточные и стабильные источники финансирования природоохранных, в т.ч. водоохранных и водохозяйственных, мероприятий.

Решение проблемы видится в следующем: необходимо вернуть платежи за водопользование в бюджет субъекта РФ. Речь идет о двух источниках финансирования - водном налоге и плате за пользование водными объектами, находящимися в федеральной собственности. В связи с этим необходимо внесение изменений в бюджетное законодательство России.

По водному налогу: следует изменить положения статьи 56 «Налоговые доходы бюджетов субъектов Российской Федерации» Бюджетного кодекса РФ, отразив распределение водного налога между федеральным бюджетом и бюджетом субъекта РФ [1]. Предлагается восстановить существовавшую ранее пропорцию: 40 и $60 \%$ соответственно.

Относительно платы за пользование водными объектами, находящимися в федеральной собственности, необходимо отметить следующее. Во-первых, необходимо внести изменения в статью 57 «Неналоговые доходы бюджетов субъектов Российской Федерации» Бюджетного кодекса РФ, отразив указанную плату в качестве источника формирования бюджетов субъектов РФ.

Во-вторых, следует изменить пункт 10 постановления Правительства РФ от 14 декабря 2006 г. № 764 «Об утверждении Правил расчета и взимания платы за пользование водными объектами, находящимися в федеральной собственности», записав его следующим образом: «Плата подлежит зачислению в федеральный бюджет и бюджеты субъектов РФ в соответствии с бюджетным законодательством Российской Федерации» [11].

В-третьих, необходимо восстановить существовавший ранее порядок 
распределения платы за пользование водными объектами, расположенными на территориях двух и более субъектов РФ.

Реализация указанных предложений позволит обеспечить полноценное и надежное финансирование водоохранных и водохозяйственных мероприятий в Республике Бурятия и других российских регионах.

\section{СПИСОК ЛИТЕРАТУРЫ}

1. Бюджетный кодекс РФ // Российская газета. 12.08.1998. № 153-154.

2. Водный кодекс Российской Федерации от 03.06.2006 г. № 74 // Собрание законодательства Российской Федерации. 05.06.2006. № 23. Ст. 2381.

3. Водный кодекс РСФСР // Ведомости Верховного Совета РСФСР. 1972. № 27. Ст. 692.

4. Водный кодекс РФ // Собрание законодательства Российской Федерации. 20.11.1995. № 47. Ст. 4471.

5. О внесении изменений в часть вторую Налогового кодекса Российской Федерации, изменения в статью 19 Закона Российской Федерации «Об основах налоговой системы в Российской Федерации», а также о признании утратившими силу отдельных законодательных актов Российской Федерации: Федеральный закон № 83-Ф3 от 28.07.2004 // Российская газета. 31.07.2004. № 162.

6. О внесении изменений и дополнений в Федеральный закон «О плате за пользование водными объектами»: Федеральный закон № 111-Ф3 от 07.08.2001 // Российская газета. 09.08.2001. № 151-152.

7. О плате за пользование водными объектами: Федеральный закон № 71-Ф3 от 06.05.1998 // Собрание законодательства Российской Федерации. 1998. № 19. Ст. 2067.

8. Об охране озера Байкал: Федеральный закон № 94-Ф3 от 01.05.1999 // Российская газета. 12.05.1999. № 90 .

9. Об охране окружающей природной среды: Закон РСФСР // Ведомости Съезда народных депутатов РФ и Верховного Совета РФ. 05.03.1992. № 10. Ст. 457.

10. Об утверждении минимальных и максимальных ставок платы за пользование водными объектами по бассейнам рек, озерам, морям и экономическим районам: Постановление Правительства РФ № 826 от 28.11.2001 // Российская газета. 08.12.2001. № 242 .

11. Об утверждении Правил расчета и взимания платы за пользование водными объектами, находящимися в федеральной собственности: Постановление Правительства РФ № 764 от 14.12.2006 // Российская газета. 20.12.2006. № 286. 